\title{
G. Savarese, Giulio II in una novella di Balzac
}

\section{Marco Stupazzoni}

\section{(2) OpenEdition}

\section{Journals}

\section{Edizione digitale}

URL: http://journals.openedition.org/studifrancesi/10675

DOI: 10.4000/studifrancesi. 10675

ISSN: 2427-5856

\section{Editore}

Rosenberg \& Sellier

\section{Edizione cartacea}

Data di pubblicazione: 1 décembre 2017

Paginazione: 566

ISSN: 0039-2944

\section{Notizia bibliografica digitale}

Marco Stupazzoni, «G. Savarese, Giulio II in una novella di Balzac», Studi Francesi [Online], 183 (LXI | III) | 2017, online dal 01 février 2018, consultato il 22 janvier 2021. URL: http://journals.openedition.org/ studifrancesi/10675 ; DOI: https://doi.org/10.4000/studifrancesi.10675

Questo documento è stato generato automaticamente il 22 janvier 2021.

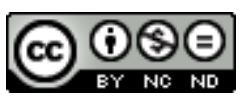

Studi Francesi è distribuita con Licenza Creative Commons Attribuzione - Non commerciale - Non opere derivate 4.0 Internazionale. 


\title{
G. Savarese, Giulio II in una novella di Balzac
}

\author{
Marco Stupazzoni
}

\section{NOTIZIA}

GeNNARO SAVARESE, Giulio II in una novella di Balzac, in "Cum fide amicitia". Per Rosanna

Alahique Pettinelli, a cura di Stefano Benedetti, Francesco Lucioli, Pietro Petrutti

Pellegrino, Roma, Bulzoni Editore, 2015, «Studi (e testi) italiani», pp. 521-529.

1 Ambientata in un Rinascimento italiano piuttosto convenzionale, la storia di Don Giovanni narrata da Balzac ne L'Élixir de longue vie rivela un interesse particolare nell'apparizione di papa Giulio II nel corso delle vicende e della storia del protagonista. Nel discorso di Don Giovanni morente al figlio Filippo, Giulio II appare non soltanto come amico del personaggio, ma soprattutto come il donatore, a lui, del miracoloso elisir di lunga vita. Secondo G. Savarese, Balzac avrebbe tratto le fonti di informazione su una figura storica di così elevato spessore come papa Giulio II dalla Biographie universelle del Michaud. Nonostante «il minimo di violenza anacronistica consentita al romanziere» (p. 529), alcuni elementi storicizzanti sulla figura del pontefice sono, in questa peinture balzachiana, pertinenti e ben articolate. Tuttavia, osserva l'A., «il tratto della novella in cui al papa Della Rovere è riservata una più ampia e significativa presenza è quello che [...] è quasi un excursus storico-critico sul costituirsi del mito di Don Giovanni, e trait d'union tra il periodo ferrarese e quello spagnolo dell'eroe balzacchiano» (p. 525). 